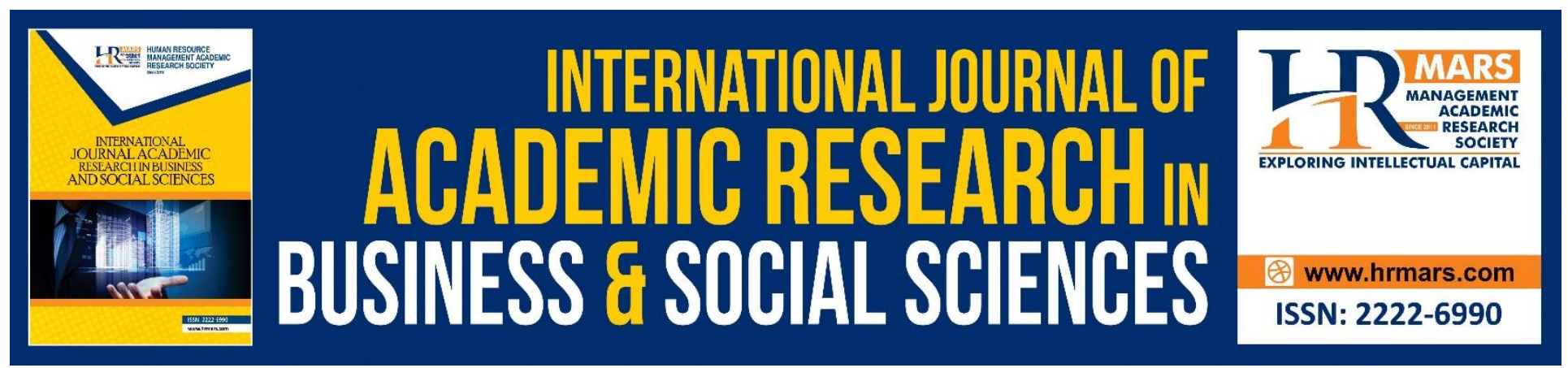

\title{
An Overview of Implicit Racial Stereotype in Malaysia
}

Rohaizahtulamni Radzlan, Mohd Ibrani Shahrimin Adam Assim, Mohd Roslan Rosnon, Shamsul Amri Baharuddin, Sarjit S. Gill \& Shamsul Azahari Zainal Badari

To Link this Article: http://dx.doi.org/10.6007/IJARBSS/v8-i12/5412

DOI: $10.6007 /$ IJARBSS/v8-i12/5412

Received: 02 Dec 2018, Revised: 30 Dec 2018, Accepted: 05 Jan 2019

Published Online: 11 Jan 2019

In-Text Citation: (Radzlan et al., 2018)

To Cite this Article: Radzlan, R., Assim, M. I. S. A., Rosnon, M. R., Baharuddin, S. A., Gill, S. S., \& Badari, S. A. Z. (2018). An Overview of Implicit Racial Stereotype in Malaysia. International Journal of Academic Research in Business and Social Sciences, 8(12), 2128-2135.

Copyright: (C) 2018 The Author(s)

Published by Human Resource Management Academic Research Society (www.hrmars.com)

This article is published under the Creative Commons Attribution (CC BY 4.0) license. Anyone may reproduce, distribute, translate and create derivative works of this article (for both commercial and non-commercial purposes), subject to full attribution to the original publication and authors. The full terms of this license may be seen at: http://creativecommons.org/licences/by/4.0/legalcode

Vol. 8, No. 12, 2018, Pg. 2128 - 2135

http://hrmars.com/index.php/pages/detail/IJARBSS

JOURNAL HOMEPAGE

Full Terms \& Conditions of access and use can be found at http://hrmars.com/index.php/pages/detail/publication-ethics 


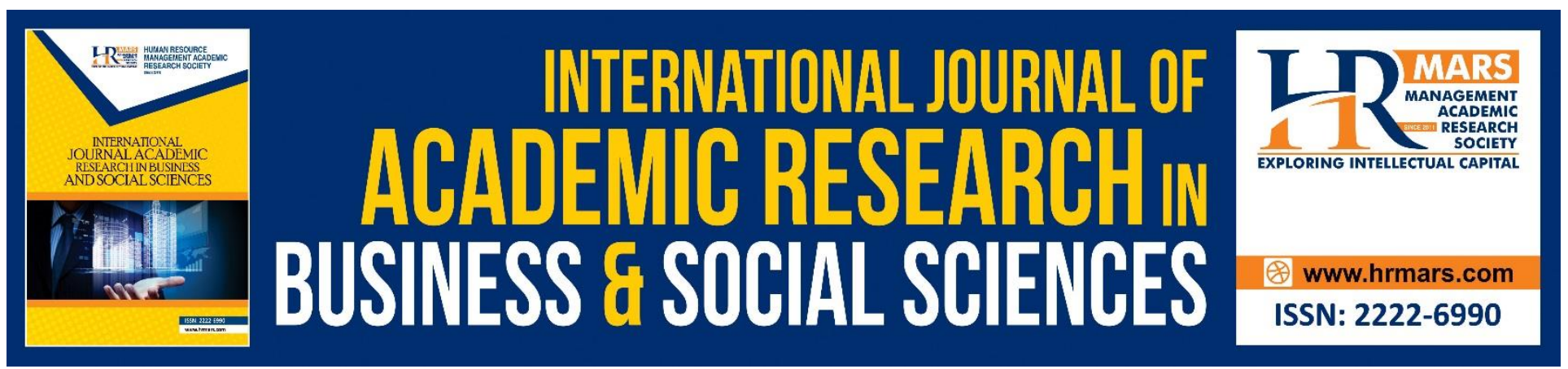

\title{
An Overview of Implicit Racial Stereotype in Malaysia
}

\author{
Rohaizahtulamni Radzlan, Mohd Ibrani Shahrimin Adam Assim, \\ Mohd Roslan Rosnon, Shamsul Amri Baharuddin, Sarjit S. Gill \& \\ Shamsul Azahari Zainal Badari \\ Department of Social and Development Science, Faculty of Human Ecology, University Putra \\ Malaysia, Malaysia \\ Institute of Ethnic Studies (KITA), Universiti Kebangsaan Malaysia, Malaysia \\ Email: amniradzlan@gmail.com
}

\begin{abstract}
Based on the concept of social psychology, a stereotype is a scheme or general knowledge structure associated with the characteristics, attribute and behaviour of group members. Therefore, sociocultural diversity in Malaysia has created a broad spectrum of stereotypical and prejudiced views to describe a particular ethnic group. However, discussing sensitive issues such as stereotyping and prejudice in general often give discomfort. Thus, the emergence of implicit measurements is one of the revolutions of stereotyping and attitudes to enable the assessment of attitudes towards sensitive social domains which can be evaluated through spontaneous and automatic representation that cannot be accessed by traditional questionnaires. Hence, this paper focuses on the topic briefly on the basic terminology and understanding of the measurement of implicit stereotypes adopted by the society in Malaysia.
\end{abstract}

Keywords: Measurement, Implicit, Stereotype, Racial, Implicit Social Cognition

\section{Introduction}

Stereotypes are beliefs about the characteristics, attributes and behaviours of certain group members (Hilton \& Von Hippel, 1996; Ajtony, 2011). Based on the concept of social psychology, the stereotype is a common knowledge schema or structure related to the character, attribute, and behaviour of the group members (Fiske, 1998; Shechory, Nachson \& Glicksohn, 2010). Besides that, the stereotyping process emerged as a way to make it easier when perceptions took place (Bodenhausen, Sheppard \& Kramer, 1994) by processing information based on stored knowledge (Hilton \& von Hippel 1996; Ajtony, 2011). Therefore, people build their own interpretation and give meaning to the phenomenon that occurs around them through the process of social perception (Ismail Sualman, 1998). Hence, every community group will go through the process of social perception to facilitate the communication process as a result of various cultures. The diversity in Malaysia has created stereotypical views to illustrate specific ethnic groups. 
Based on the sociocultural history of Malaysia, the colonial policy has resulted in the increase of immigrant Chinese and Indian ethnic while creating a stratification of jobs according to groups. The phenomenon has created various social perceptions and racial stereotypes such as the Malay ethnic who live in the village are regarded as 'farmers or fishermen', Chinese ethnic in mines or towns are 'miners and traders' as well as Indian ethnics in rubber estates as 'tappers or labourers' (Razaleigh, Abdul Ghafar, Salasiah, Fariza, Badlihisham, Muhammad Faisal, Siti Rugayah, Zainab, Ideris, Anuar, A'dawiyah \& Mohd Zulkipli, 2012). Meanwhile, the study by Rabushka (1973); Norraesah (2005) \& Faisal, Norhayati, Thong, Ezhar, Khairul \& Zalina (2010), stated that most students often associate Malay ethnicity as 'lazy'. 'Lazy' is a word that is often associated with the Malay ethnic when they are working or completing an assignment. One of the reasons for this is the power of association, lazy words were often used by the Malay ethnic as a universal verse to replace reasons such as 'unhealthy', 'tired' or 'busy' (Asrul, 2002). Harmiza (2015), also noted that some of the strong perceptions that existed among Malay and Chinese ethnic youths were the perceptions inherited from the past and their surrounding communities. Chinese is often associated with 'most successful and wealthy traders'. Meanwhile, the Malay ethnic is often associated with 'Lan ren' (懶人), also known as lazy. Such perceptions occur as Malay ethnic groups are often given advantages over other ethnic groups, thus the latter need to work harder to get a comfortable life.

Another study stated that stereotype and ethnic relations in Malaysia have to change. Khalim \& Norshidah (2012), explaining that young people are aware of the need to maintain close ties between other ethnic groups to achieve economic stability. Additionally, the government's emphasis on the importance of education in inter-racial relations and emphasizing on the issue of unity among groups in Malaysia have brought good results. Revisiting Racial Stereotype in Malaysia research by Mansor \& Nazri (2014), explained that racial stereotypes now do not affect behaviour in other groups. Similarly, a study by Harmiza (2015) on the impression between ethnic groups and their impact on ethnic relations among the Malay and Chinese youth in peninsular Malaysia found negative stereotypes, yet the views among the Malay and Chinese youths did not affect the relationship with other races. However, caution must be practiced when dealing with different races as racial issues were considered "sensitive", hence should not be discussed and dealt with in general (Noraini, 2007). Discussion of stereotype and prejudice is often an uncomfortable topic as a norm. They believe that discussing sensitive issues is equivalent to a social mistake, by accidentally laughing, or appearing prejudice (Stephan \& Stephan, 2001; Kite \& Whitley, 2012). Hence, this study attempts to explain "unspoken stereotypes" or stereotypes that cannot be expressed freely towards Malay and Chinese ethnic groups through the implicit approach of implicit social cognition using implicit measurements.

\section{Literature Review}

In 1995, Greenwald and Banaji introduced the term 'implicit social cognition' to illustrate the cognitive processes that occur beyond conscious awareness or conscious control in relation to psychological social constructs, such as attitude, stereotype, and self-concept (Nosek, Hawkins, \& Frazier, 2011). In addition to that, implicit social cognition is a descriptive term that includes thoughts and emotions, either occurring independently of conscious, unconscious, or controlled intentions 
(Greenwald \& Banaji, 1995; Nosek \& Greenwald, 2009; Nosek, Hawkins, \& Frazier, 2011; Nosek \& Riskind, 2012). Hence, the term implicit social cognition refers to social psychology research as well as areas related to computerized measurement to evaluate thoughts and feelings without asking respondents directly and report it (Gawronski \& Payne, 2010). Accordingly, based on the context of the previous study explains that implicit social cognition is the impression of a past experience that is not substantially remembered but influenced by some implementation, and this process does not exist in explicit or introspection measurement (Jacoby, Lindsay, \& Toth, 1992; Greenwald \& Banaji, 1995). Therefore, research in this field, inspired by cognitive research, is an implicit memory that explains the influence of past experiences on the implementation of psychological functions (Payne \& Gawronski, 2010).

\section{Implicit Measure}

One of the significant contributions of social cognition research in the last decade was the establishment of implicit measurements of attitudes, stereotypes, self-concepts, and self-esteem (Rezaei, 2011). Measurements in implicit social cognition were often referred to as implicit measurement, while traditional self-report measurements were described as explicit measurement (Hahn \& Gawronski, 2015). There were two main features of implicit measurement, firstly was to overcome the measurement problems associated with self-definition and social desirability and secondly was to control thoughts and feelings beyond the conscious consciousness that cannot be achieved in explicit measurement (Devezas \& Giesteira, 2014; Hahn \& Gawronski, 2015). In addition to that, implicit measurements were indirect techniques that utilize the uncontrollable latency measure (Laurie, 2011). Therefore, the conceptual basis for measurement in implicit social cognition was the process of mental affiliation or thought (Hahn \& Gawronski, 2015). Hence, implicit measurement classified the stimulus by representing two concepts of objects (e.g. Malay vs. Chinese) and identifying two concepts of attributes (e.g. fun vs. objectionable) by pressing buttons on computer keyboards (Greenwald, McGhee and Schwartz, 1998; Frost et al., 2010). Among the wellknown implicit measure are priming assessments and the Implicit Association Test (IAT) en masse.

The Implicit Association Test (IAT) is the most recognizable measurement of implicit social cognition introduced by Greenwald, McGhee and Schwartz in 1998 (Greenwald et al, 1998; Nosek, Stanley, Phelps, \& Banaji, 2008; Nosek et al, 2011). Technically, IAT is a computer-administered test to evaluate the automatic association between the object and attribute (Greenwald \& Banaji, 1995; Greenwald et al., 2002; Quek \& Ortony, 2012). IAT uses time-based reaction speed in assessing the relative strength of the object and attribute (Nosek \& Riskind, 2012). Hence, IAT is currently the most accurate measure of implicit attitude (Nosek, Greenwald \& Banaji, 2007; Greenwald, Poehlman, Uhlmann \& Banaji, 2009) as well as IAT Race (Black vs. White vs. Good vs. Bad) as they are widely used in research (Xu, Nosek, \& Greenwald, 2014). In this study, IAT was modified according to sociocultural in Malaysia and called Malaysia Reconciliation Identity (MyRId). Here, Figure 1 showed the MyRId illustration of the Malay-Chinese set based on the sociocultural in Malaysia. 
INTERNATIONAL JOURNAL OF ACADEMIC RESEARCH IN BUSINESS AND SOCIAL SCIENCES

Vol. 8, No. 12, Dec, 2018, E-ISSN: 2222-6990 @ 2018 HRMARS

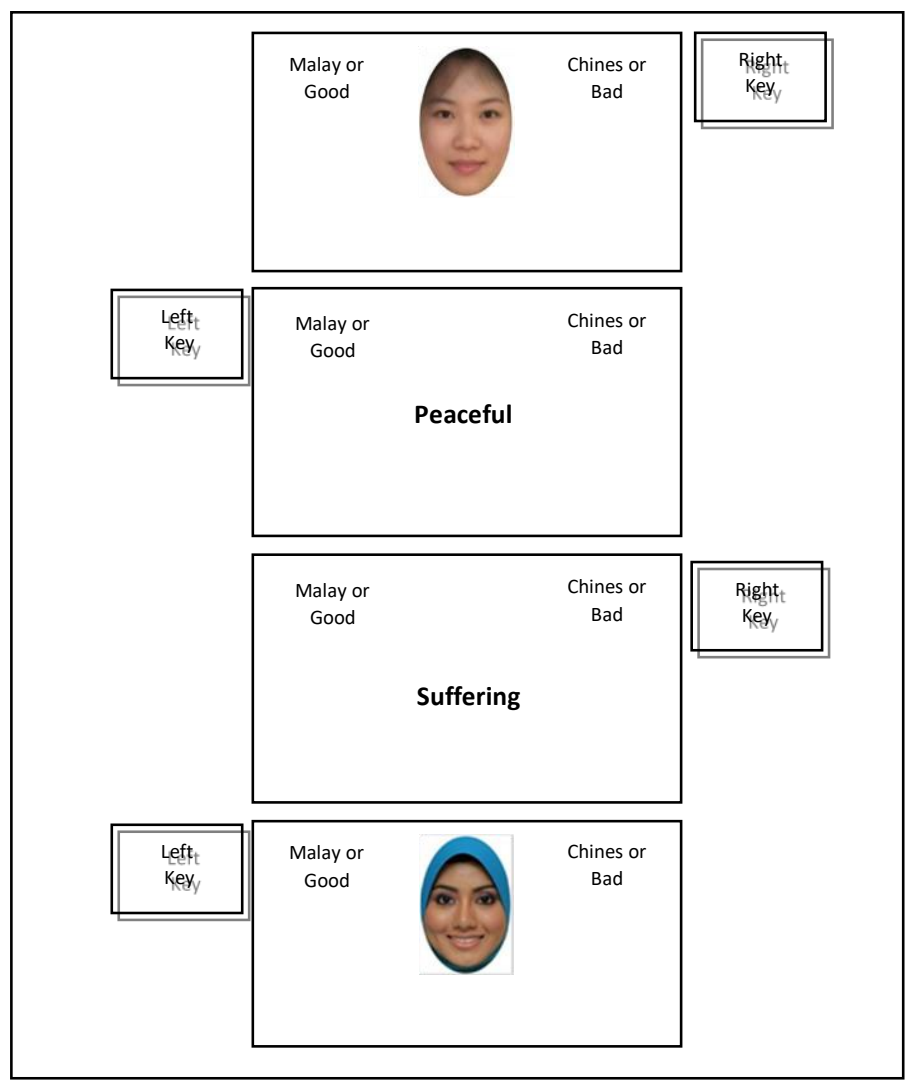

Figure 1: Illustration of Instrumentation Implicit Stereotype

Figure 1 shows four series sequences that were likely to occur during the MyRId test. For instance, the Malay words or fun words shared the same keyboard response, while Chinese words or unpleasant words shared the opposite keyboard. Each subject will only press one of the computer's keyboard to respond to the stimulus. In this study, MyRId measurements had set the "A" key to represent for the left response, while the "L" key represented the right response on the keyboards respectively. Description of keyboard usage was specified before the subject runs MyRId test in computer view. The operations and processes that occurred in MyRId were automated responses known as the latency of two categories of stimuli through motor response. Hence, the measurements calculated the amount of response time to the stimulus. Reaction or response must be done rapidly for implicit measurements and each attempt to solve it should not exceed 3000ms.

The calculation of $300 \mathrm{~ms}$ total time measurements for the minimum number and $3000 \mathrm{~ms}$ for the maximum for a series of questions used (Greenwald, McGhee \& Schwartz, 1998) similar to other implicit studies. The amount of time each series of questions were added and rejected were based on the blocks that did not match the corresponding block. If the total amount of time is positive, it indicated that an individual is more likely in the Malay ethnic group than the Chinese ethnic group and vice versa. Based on implicit stereotypical studies in America, there were strong association of African American names as negative words and strong links between White Caucasian names with 
positive words (Greenwald et al., 1998). All in all, this study found that the strong link between Malaybad/Chinese-good or Malay-good/Chinese-bad portrayed implicit stereotypes. Findings also shown that the strength difference of the response process was influenced by the compatibility attitude towards the coupling of the pair of categories among the concepts of objects and attributes.

\section{Contributions}

Overall, this study aims to explain how "unspoken stereotypes" or stereotypes cannot be expressed freely on the socio-cultural context in Malaysia, particularly towards the ethnic Malays and Chinese through implicit social cognition approaches. This is because, the implicit approach of implicit social cognition using implicit measurements clarifies the mental content that cannot be clearly explained.

\section{Acknowledgement}

This work is supported by the Institute of Ethnic Study (KITA), Universiti Kebangsaan Malaysia under the Long-term Research Grant Schema (LRGS)-Universiti Kebangsaan Malaysia/Universiti Putra Malaysia.

\section{Corresponding Author}

Assoc. Prof. Dr. Mohd Ibrani Shahrimin Adam

Department of Social and Development Science, Faculty of Human Ecology,

Universiti Putra Malaysia, 43400 UPM Serdang

Email: ibrani@putra.upm.edu.my

\section{References}

Ajtony, Z. (2011). Ethnic Stereotype- Impediments or Enhancers of Social Cognition? Acta Universitatis Sapientiae. Philogica, 3 (2), 134-155.

Asrul, Z. (2002). The Malay Ideals. Kuala Lumpur: Golden Books Centre Sdn. Bhd.

Bodenhausen, G. V., Sheppard, L. A., \& Kramer, G. P. (1994). Negative Affect and Social Judgment: The Differential Impact of Anger and Sadness. European Journal of Social Psychology, 24, 4562.

Devezas, T., \& Giesteira, B. (2014). Using the Implicit Association Test for Interface-Based Evaluations. In The Seventh International Conference on Advances in Computer-Human Interactions, 9-16.

Faisal, I., Norhayati, A. M., Thong, L. K., Ezhar, T., Khairul, H., \& Zalina, D. (2010). Re-Visiting Malay Stereotypes: A Case Study among Malaysian And Indonesian Chinese Students. ResearchGate, $3(2), 153-163$.

Fiske, S. T. (1998). Stereotyping, Prejudice, and Discrimination. The handbook of social psychology, 2 (4), $357-411$. 
INTERNATIONAL JOURNAL OF ACADEMIC RESEARCH IN BUSINESS AND SOCIAL SCIENCES

Vol. 8, No. 12, Dec, 2018, E-ISSN: 2222-6990 @ 2018 HRMARS

Frost, P., Adie, M., Denomme, R., Lahaie, A., Sibley, A., \& Smith, E. (2010). Application of the Implicit Association Test to a Study on Deception. The American Journal of Psychology, 123 (2), 221 230.

Gawronski, B., \& Payne, B. K. (2010). Handbook of Implicit Social Cognition: Measurement, Theory, and Applications. New York: Guilford Press.

Greenwald, A. G., \& Banaji, M. R. (1995). Implicit Social Cognition: Attitudes, Self-Esteem, and Stereotypes. Psychological Review, 102 (1), 4- 27.

Greenwald, A. G., McGhee, D. E., \& Schwartz, J. L. K. (1998). Measuring Individual Differences in Implicit Cognition: The Implicit Association Test. Journal of Personality and Social Psychology, 74 (6), $1464-1480$.

Greenwald, A. G., Poehlman, T. A., Uhlmann, E. L., \& Banaji, M. R. (2009). Understanding and Using the Implicit Association Test: III. Meta-Analysis of Predictive Validity. Journal of Personality and Social Psychology, 97(1), 17-41.

Greenwald, A. G., Rudman, L. A., Nosek, B. A., Banaji, M. R., Farnham, S. D., \& Mellott, D. S. (2002). A Unified Theory of Implicit Attitudes, Stereotypes, Self-Esteem, and Self-Concept. Psychological Review, 109 (1), 3 - 25.

Hahn, A., \& Gawronski, B. (2015). Implicit Social Cognition. International Encyclopedia of the Social \& Behavioral Sciences (Second Edi, Vol. 11). Elsevier.

Harmiza, M. M. (2015). Persepsi antara Etnik dan Impaknya terhadap Hubungan Etnik dalam Kalangan Belia Melayu dan Cina di Semenanjung Malaysia. Master thesis, Universiti Putra Malaysia (unpublished).

Hilton, J. L., \& Von Hippel, W. (1996). Stereotypes. Annual Review of Psychology, 47 (1), 237- 271.

Ismail Sualman. (1998). Fenomena Stereotaip: Kesannya Ke Atas Komunikasi. Retrieved November 5th, $2015 . \quad$ Dimuat turun daripada http://ir.uitm.edu.my/3547/1/LP_ISMAIL_SUALMAN_98_24.pdf.

Jacoby, L. L., Lindsay, D. S., \& Toth, J. P. (1992). Unconscious influences revealed: Attention, awareness, and control. American Psychologist, 47(6), 802-809.

Khalim, Z., \& Norshidah, M. S. (2012). A Case Study of Ethnic Behavior among Students in Urban and Rural Schools. The International Journal of Knowledge, Culture, \& Change Management, 11 (3), $161-169$.

Kite, M. E., \& Whitley, B. E. (2012). Ethnic and Nationality Stereotypes in Everyday Language. Teaching of Psychology, 39 (1) 54 - 56.

Mansor, M. N., \& Nazri, M. (2014). Revisiting Racial Stereotype in Malaysia. Middle-East Journal of Scientific Research, 21 (8), 1312 - 1316.

Noraini, M. N. (2007). Polarisation and inequality in Malaysia: The future of Malay-Chinese relations. Intellectual Discourse, 15 (2), 191 - 204.

Norraesah Mohammad. (2005). The Malays in Business and Entrepreneurship. Perak, Malaysia: Penerbit Universiti Pendidikan Sultan Idris.

Nosek, B. A., \& Greenwald, A. G. (2009). The Case for a Pragmatic Approach to validity. Psychological Bulletin, 135, $373-376$. 
Nosek, B. A., Greenwald, A. G., \& Banaji, M. R. (2007). The Implicit Association Test at Age 7: A Methodological and Conceptual Review. In J. A. Bargh (Ed.), Automatic Processes in Social Thinking and Behavior (pp. 265-292). New York: Psychology Press.

Nosek, B. A., Hawkins, C. B., \& Frazier, R. S. (2011). Implicit Social Cognition : From Measures to Mechanisms. Trends in Cognitive Sciences, 15 (4), 152 - 159.

Nosek, B. A., \& Riskind, R. G. (2012). Policy Implications of Implicit Social Cognition. Social Issues and Policy Review, 6 (1), $113-147$.

Quek, B-K. \& Ortony, A. (2012). Assessing Implicit Attitudes: What can be learned from Simulations? Social Cognition, 30 (5), 610 - 630.

Rezaei, A. R. (2011). Validity and Reliability of the IAT: Measuring Gender and Ethnic Stereotypes. Computers in Human Behavior, 27 (5), 1937 - 1941.

Razaleigh, M., Abdul Ghafar, D., Salasiah, H. H., Fariza, M. S., Badlihisham, M. N., Muhammad Faisal, A., Siti Rugayah, T., Zainab, I., Ideris, E., Anuar, P., A'dawiyah, I., \& Mohd Zulkipli, A. G. (2012). The History of Ethnic Relationship in Malaysia. Advances in Natural and Applied Sciences, 6 (4), $504-510$.

Rabushka, A. (1973). Race and Politics in Urban Malaya. Stanford, California: Hoover Institution Press, Stanford University.

Stanley, D., Phelps, E., \& Banaji, M. (2008). The Neural Basis of Implicit Attitudes. Association for Psychological Science, 17 (2), $164-170$.

Stephan, C. W., \& Stephan, W. G. (2001). Improving Intergroup Relations. Mahwah, NJ: Lawrence Erlbaum.

Shechory, M., Nachson, I., \& Glicksohn, J. (2010). Effects of Stereotypes and Suggestion on Memory. International Journal of Offender Therapy and Comparative Criminology, 54 (1), 113 - 130.

Payne, B. K., \& Gawronski, B. (2010). A History Of Implicit Social Cognition: Where Is It Coming From? Where is it now? Where is it going? New York, NY: Guilford Press.

Xu, K., Nosek, B., \& Greenwald, A. G. (2014). Data from the Race Implicit Association Test on the Project Implicit Demo Website. Journal of Open Psychology Data, 2(1), 3. 